\title{
A modified tank model including snowmelt and infiltration time lags for deep-seated landslides in alpine environments (Aggenalm, Germany)
}

\author{
Wen Nie $^{1}$, Michael Krautblatter ${ }^{1}$, Kerry Leith ${ }^{1}$, Kurosch Thuro ${ }^{2}$, and Judith Festl ${ }^{3}$ \\ ${ }^{1}$ Landslide Research, Faculty of Civil, Geo and Environmental Engineering, Technische Universität München, \\ Munich, Germany \\ ${ }^{2}$ Engineering Geology, Faculty of Civil, Geo and Environmental Engineering, Technische Universität München, \\ Munich, Germany \\ ${ }^{3}$ Baugeologisches Büro Bauer GmbH, Domagkstraße 1a, 80807 Munich, Germany
}

Correspondence to: M. Krautblatter (m.krautblatter@tum.de)

Received: 15 December 2015 - Discussion started: 18 January 2016

Revised: 10 August 2017 - Accepted: 13 August 2017 - Published: 22 September 2017

\begin{abstract}
Deep-seated landslides are an important and widespread natural hazard within alpine regions and can have significant impacts on infrastructure. Pore water pressure plays an important role in determining the stability of hydrologically triggered deep-seated landslides. Based on a simple tank model structure, we improve groundwater level prediction by introducing time lags associated with groundwater supply caused by snow accumulation, snowmelt and infiltration in deep-seated landslides. In this study, we demonstrate an equivalent infiltration calculation to improve the estimation of time lags using a modified tank model to calculate regional groundwater levels. Applied to the deep-seated Aggenalm landslide in the German Alps at 1000-1200 ma.s.1., our results predict daily changes in pore water pressure ranging from -1 to $1.6 \mathrm{kPa}$, depending on daily rainfall and snowmelt, which are compared to piezometric measurements in boreholes. The inclusion of time lags improves the results of standard tank models by $\sim 36 \%$ (linear correlation with measurement) after heavy rainfall and by $\sim 82 \%$ following snowmelt in a 1-2-day period. For the modified tank model, we introduced a representation of snow accumulation and snowmelt based on a temperature index and an equivalent infiltration method, i.e. the melted snow-water equivalent. The modified tank model compares well to borehole-derived water pressures. Changes of pore water pressure can be modelled with $0-8 \%$ relative error in rainfall season (standard tank model: $2-16 \%$ relative error) and with $0-7 \%$ relative
\end{abstract}

error in snowmelt season (standard tank model: $2-45 \%$ relative error). Here we demonstrate a modified tank model for deep-seated landslides which includes snow accumulation, snowmelt and infiltration effects and can effectively predict changes in pore water pressure in alpine environments.

\section{Introduction}

Deep-seated landslides in the European Alps and other mountain environments pose a significant hazard to people and infrastructure (Mayer et al., 2002; Madritsch and Millen, 2007; Agliardi et al., 2009). It has long been recognized that pore water pressure (PWP) changes by precipitation play a critical role for hydrologically controlled deep-seated landslide activation. The rise in PWP causes a drop of effective normal stress on potential sliding surfaces (Bromhead, 1978; Iverson, 2000; Wang and Sassa, 2003; Rahardjo et al., 2010). The estimation of pore water pressure is of great significance for anticipating deep-seated landslide stability. In past years, geotechnical monitoring systems have revealed PWP changes related to rainfall and snowmelt events (Angeli et al., 1988; Simoni et al., 2004; Hong et al., 2005; Rahardjo et al., 2008). Generally, two ways are employed to estimate the groundwater changes: (1) depending on the precise information of permeability and infiltration of material, the Green and Ampt model is generally used to describe ground- 
water infiltration and water table changes (producing PWP) in saturated material (Chen and Young, 2006). The Richards equation (Weill et al., 2009) with the Van Genuchten equation (Schaap and Van Genuchten, 2006) or the Fredlund and Xing (1994) method show better performance in the evaluation of infiltration and groundwater table in unsaturated material. Traditional deterministic models have advantages due to their explicit physical and mechanical approaches, but they require accurate knowledge, testing and monitoring of soil physical parameters, which are often not available with sufficient accuracy. For example, the widely used Richards equation with the Van Genuchten method needs soil suction tests under variable moisture content, saturated water content, residual water content and the pore-size distribution of materials, which are difficult to achieve for complex landslides with multiple reworked materials. (2) Empiricalstatistical models employ optimization or fitting parameters in their model structure. Tank and other models need historical monitoring data to train parameters (Faris and Fathani, 2013; Abebe et al., 2010). Such empirical models, because of their simple conceptualized structure, do rely to a smaller degree on explicit physical and mechanical approaches. However, they can avoid the problems induced by the uncertainty of material parameterization and its spatial arrangement in the landslide mass. They can, therefore, be applied to a wide range of different landslide settings and we estimate that for more than $90 \%$ of all landslides no explicit parameters on soil suction are available. As one of the most common empirical models, tank models typically describe infiltration and evaporation in shallow soil materials (Ishihara and Kobatake, 1979). They are based on the water balance theory, which means they account for flows into and out of a particular drainage area. Multi-tank models involving two or three tank elements have been developed to better estimate groundwater fluctuations within shallow landslides induced by heavy rainfall (Michiue, 1985; Ohtsu et al., 2003; Takahashi, 2004; Takahashi et al., 2008; Xiong et al., 2009).

Figure 1a shows the work mode of a simple tank model.

$h_{i+1}-h_{i}=R_{i}-q_{i}$,

$q_{i}=a h_{i}$,

where $R_{i}$ is the rainfall and $q_{i}$ is the drainage of the $i$ th day. $h_{i}$ is groundwater table height of the $i$ th day. $a$ is the parameter for the relation between $h_{i}$ and $q_{i}$. Obviously, for the deep-seated landslides, due to the long infiltration the rainfall $\left(R_{i}\right)$ cannot totally contribute to the change of groundwater table $\left(h_{i+1}-h_{i}\right)$ within 1 day. Thus, simple tank models do not consider infiltration time lags induced by a long infiltration path, previous moisture and snowmelt. This inhibits their applicability to deep-seated landslide. In contrast, Fig. $1 \mathrm{~b}$ describes the work principle of multi-tank models in deep-seated landslides mainly considering the vertical infiltrations.

$\mathrm{h} 1_{i+1}-\mathrm{h} 1_{i}=R_{i}-\mathrm{d} 1_{i}$

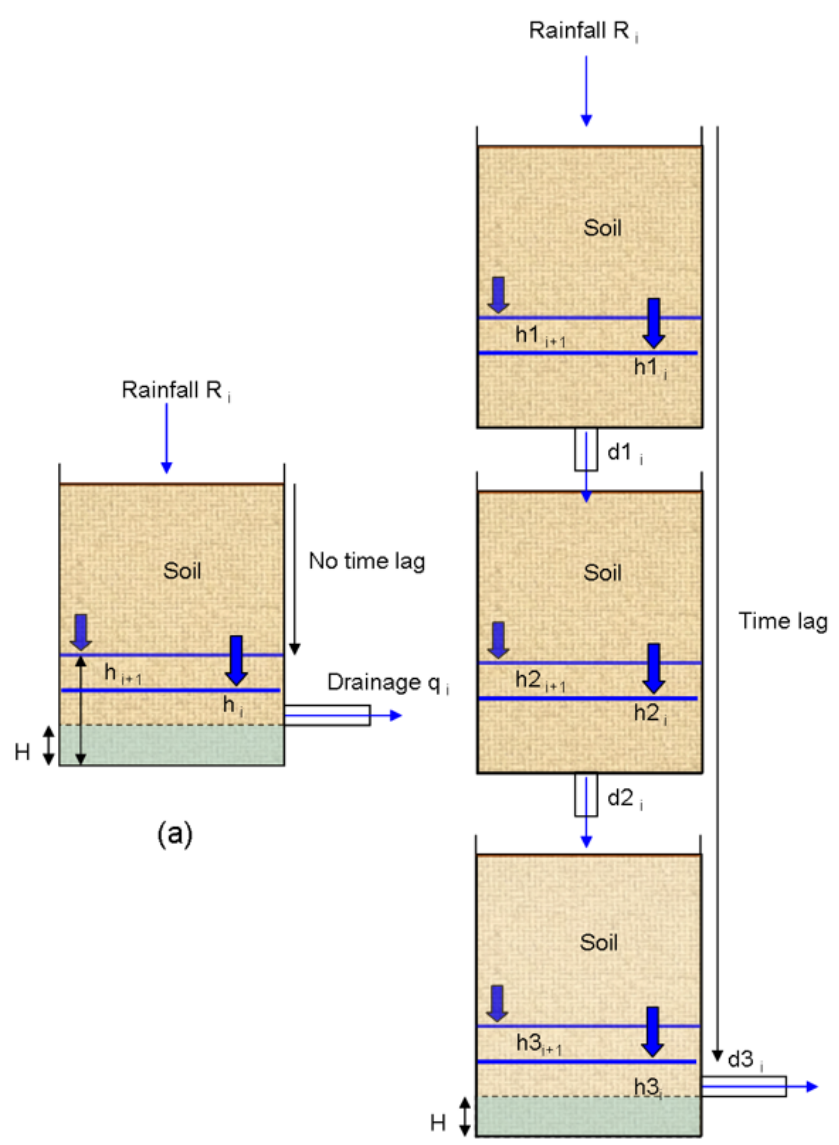

(b)

Figure 1. Details of simple tank model and multi-tank model applied in deep-seated landslides. (a) Schematic diagram of simple tank model. (b) Schematic diagram of multi-tank model.

$\mathrm{d} 1_{i}=\mathrm{a} 1 \mathrm{~h} 1_{i}$

where $\mathrm{h} 1_{i+1}$ and $\mathrm{h} 1_{i}$ are water table levels of the $i+1$ th and $i$ th day in higher soil layer, $\mathrm{d} 1_{i}$ is the infiltration of the $i$ th day in middle soil layer, a1 is parameter of relation between $\mathrm{h} 1_{i}$ and $\mathrm{d}_{i}$, and $R_{i}$ is the rainfall of the $i$ th day.

$\mathrm{h} 2_{i+1}-\mathrm{h} 2_{i}=\mathrm{d} 1_{i}-\mathrm{d} 2_{i}$

$\mathrm{d} 2_{i}=\mathrm{a} 2 \mathrm{~h} 2_{i}$,

where $\mathrm{h} 22_{i+1}$ and $\mathrm{h} 2{ }_{i}$ are water table levels of the $i+1$ th and $i$ th day in middle soil layer, $\mathrm{d} 2_{i}$ is the infiltration of the $i$ th day in lower soil layer and $\mathrm{a} 2$ is the parameter of relation between $\mathrm{h} 2_{i}$ and $\mathrm{d} 2_{i}$.

$\mathrm{h} 3_{i+1}-\mathrm{h} 3_{i}=\mathrm{d} 2_{i}-\mathrm{d} 3_{i}$

$\mathrm{d} 3_{i}=\mathrm{a} 3 \mathrm{~h} 3_{i}$,

where $\mathrm{h} 3_{i+1}$ and $\mathrm{h} 3_{i}$ are water table levels of the $i+1$ th and $i$ th day in lower soil layer, $\mathrm{d} 3_{i}$ is the drainage of $i$ th day, and a3 is parameter of relation between $\mathrm{h} 3_{i}$ and $\mathrm{d} 3_{i}$. 
From the Eqs. (3) to (5), there are seven unknown ( $\mathrm{h} 1_{i+1}$, $\left.\mathrm{h} 1_{i}, \mathrm{a} 1, \mathrm{~h} 2_{i+1}, \mathrm{~h} 2_{i}, \mathrm{a} 2, \mathrm{a} 3\right)$ and three known parameters $\left(\mathrm{h} 3_{i+1}, \mathrm{~h} 3_{i}, R_{i}\right)$. In order to get the seven unknown values, even usage of some advanced algorithms does not effectively estimate the parameters. Multi-tank models can deal with infiltration time lags to some extent by adding tanks but even then they (i) require data from several monitoring boreholes to track groundwater flow supplies in complicated geological structures and (ii) are presently not designed to replicate time lags of increased infiltration, e.g. following snowmelt (Iverson, 2000; Sidle, 2006; Nishii and Matsuoka, 2010). Applying multi-tank models to compensate for time lags is questionable because deep-seated landslides in particular would need several tanks to replicate time lags and every added new tank in vertical direction introduces three new parameters at least. This would reduce robustness and reliability of system especially if we just use the monitored groundwater table for the parameter training of whole system.

In this study, we introduce a simple method to estimate time lags by a modified standard tank model which predicts changes in pore water pressure. The innovation of our approach is to calculate equivalent infiltration before it enters the tank. The equivalent infiltration deals with the infiltration time lag, including snow accumulation and snowmelt in deep-seated landslides, based on a simple tank model structure. We hypothesize and provide quantitative evidence that, compared to a simple tank model, our modified model has a higher accuracy and physical meaning by controlling equivalent infiltration, including snow accumulation and snowmelt; compared to a multi-tank model our modified model is more robust and reliable. The prediction of precipitation type is very difficult because the vertical height of snow flakes is not easily calculated without advanced technology (Czys et al., 1996; Ahrens, 2007). Thus, in our study the judgment of precipitation type still uses the widely used statistic model. For the snowmelt calculation we used empirical equations to make the process earlier, because sophisticated models which can calculate the snowmelt precisely are quite complex and require several physical parameters, including topography, precipitation, air temperature, wind speed and direction, humidity, downwelling short-wave and long-wave radiation, cloud cover and surface pressure (Garen and Marks, 2005; Herrero et al., 2009; Lakhankar et al., 2013). In addition, compared to the original tank model without considering the snowmelt, we emphasized the tank model coupling the function of snowmelt (we just choose the simple snowmelt module). We apply our model to the Aggenalm landslide, where predicted PWP changes can be tested against piezometric borehole monitoring data. The monitoring network design and installation, as well as detailed monitoring data, and the introduction of monitoring devices have been described previously in detail (Thuro et al., 2009, 2011a, b, 2013; Festl et al., 2012). It should be pointed out our aim is only to estimate the local pore water pressure in deep-seated landslides. The relation between landslide movement and the groundwater table is not the focus of this study. The landslide movement is complex and time dependent and material strength is also very important. It has been hypothesized that deep-seated landslide velocity, although linked to pore-pressure-induced changes in effective stress, is also governed by rate-induced changes in shear strength of the materials, caused by changing mechanical properties during shear deformation (Lupini et al., 1981; Skempton, 1985; Angeli et al., 1996; Picarelli, 2007) and/or consolidation and strength regain during periods of rest (Nieuwenhuis, 1991; Angeli et al., 2004).

\section{Site descriptions}

The Aggenalm landslide is situated in the Bavarian Alps in the Sudelfeld region near Bayrischzell (Fig. 2).

During the alpine orogeny, the rock mass was faulted and folded into several large east-west-oriented synclines, of which the Audorfer synclinorium is responsible for the nearly slope-parallel bedding orientation of the rock mass in the area of the Aggenalm landslide (Fig. 3).

The Aggenalm landslide is underlain by Late Triassic well-bedded limestones (Plattenkalk, predominantly Nor), overlain by Kössen layers (Rhät, predominantly marly basin facies) and the often more massive Oberrhät limestones and dolomites (Rhät) (Fig. 3). The marls of the Kössen layers are assumed to provide primary sliding surfaces and are very sensitive to weathering as they decompose over time to a clay-rich residual mass (Nickmann et al., 2006). The landslide mechanism can be classified as a complex landslide dominated by deep-seated sliding with earth flow and lateral rock spreading components (Singer et al., 2009). A major activation of the landslide occurred in 1935, destroying three bridges and a local road. Slow slope deformation and secondary debris flow activity have been ongoing since this time.

\section{Data and methods}

\subsection{Climate conditions}

The Aggenalm is exposed to a sub-continental climate with a pronounced summer precipitation maximum and an annually changing share of $15-40 \%$ of the mean annual precipitation that fall as snow. Abundant snow cover restricts freezing of the top to a few tens of centimetres, allowing water penetration in cracks. Due to the all-year humid climate (see Fig. 4; nearby meteorological stations such at the Brünnsteinhaus, the Sudelfeld (Polizeiheim) and the Tatzelwurm indicate mean annual precipitation of 1594, 1523 and $1660 \mathrm{~mm} \mathrm{a}^{-1}$ at similar elevations), the rapid drainage of water in the permeable underground (pore water pressure reduces 2-3 kPa within 15 days) and the deep-seated nature of the slope movement (depth is $30-40 \mathrm{~m}$ ), we did not explicitly 


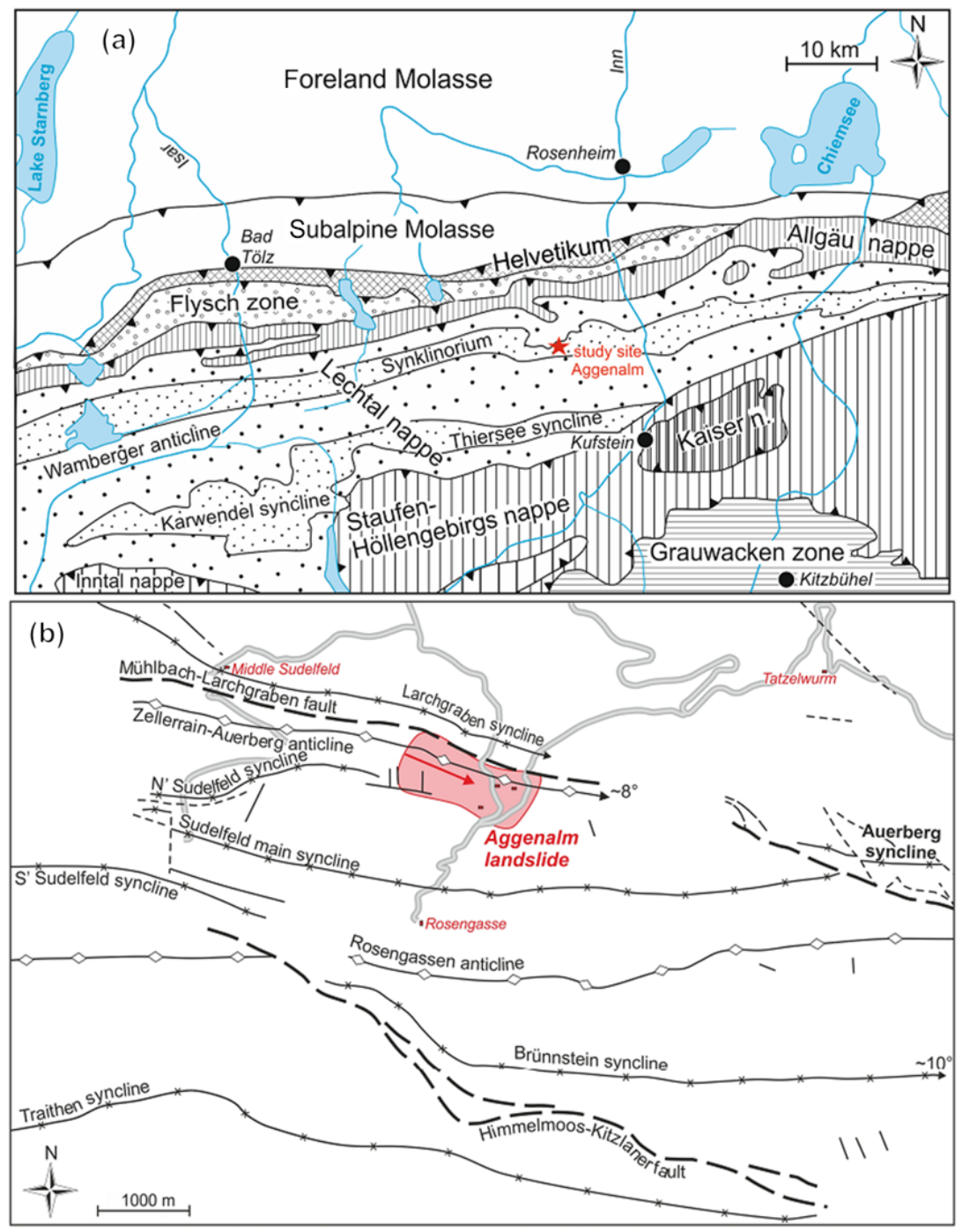

Figure 2. (a) Tectonic map of the Northern Calcareous Alps between Lake Starnberg and Lake Chiemsee. The Aggenalm landslide is situated in the Lechtal Nappe within the Synklinorium, a major syncline-anticline-syncline fold belt, which can be traced through the whole region (Schmidt-thome, 1964; Gwinner, 1971). (b) Detailed tectonic map showing the main tectonic features in the Aggenalm landslide area. Here, the Synklinorium has a complex structure with several additional minor syn- and anticlines, of which the eastward dipping of the Zellerrain-Auerberg anticline is responsible for the nearly slope-parallel orientation of the rock mass within the Aggenalm landslide (Festl, 2014).

consider evapotranspiration. However, the daily reduction of pore pressure $\left(\sim 0.3 \mathrm{kPa} \mathrm{day}^{-1}\right)$ includes an empirical component of evapotranspiration.

\subsection{Monitoring data}

Monitoring data for this study are derived from a rain gauge and humidity sensor (alpEWAS central station) and a PWP sensor installed in boreholes close to the assumed shear zone (B4, 29.4 m deep) (Fig. 3) (Singer et al., 2009; Festl, 2014). A heated precipitation gauge provides data on the snowwater equivalent of snowfall. Short-term noise in raw data was filtered. PWP, temperature and humidity are averaged over a $24 \mathrm{~h}$ period (Festl, 2014). Since the whole monitoring period lasted for almost 3 years and time lags were in the range of days, days were considered to be the most robust and appropriate standard reference time unit and would also keep results comparable to previous studies. The monitoring period lasts from February 2009 to December 2011. Considering data loss in some months, we have approximately 24 months of valid data. To parameterize the modified tank model, we use data from 13 months (May to June 2009; September to December 2009; February to August 2010). To validate the parameterized model, 55 days of rainfall (July to August 2009) and 44 days of snowmelt (March to April 2009) are used to compare model-calculated pore water 


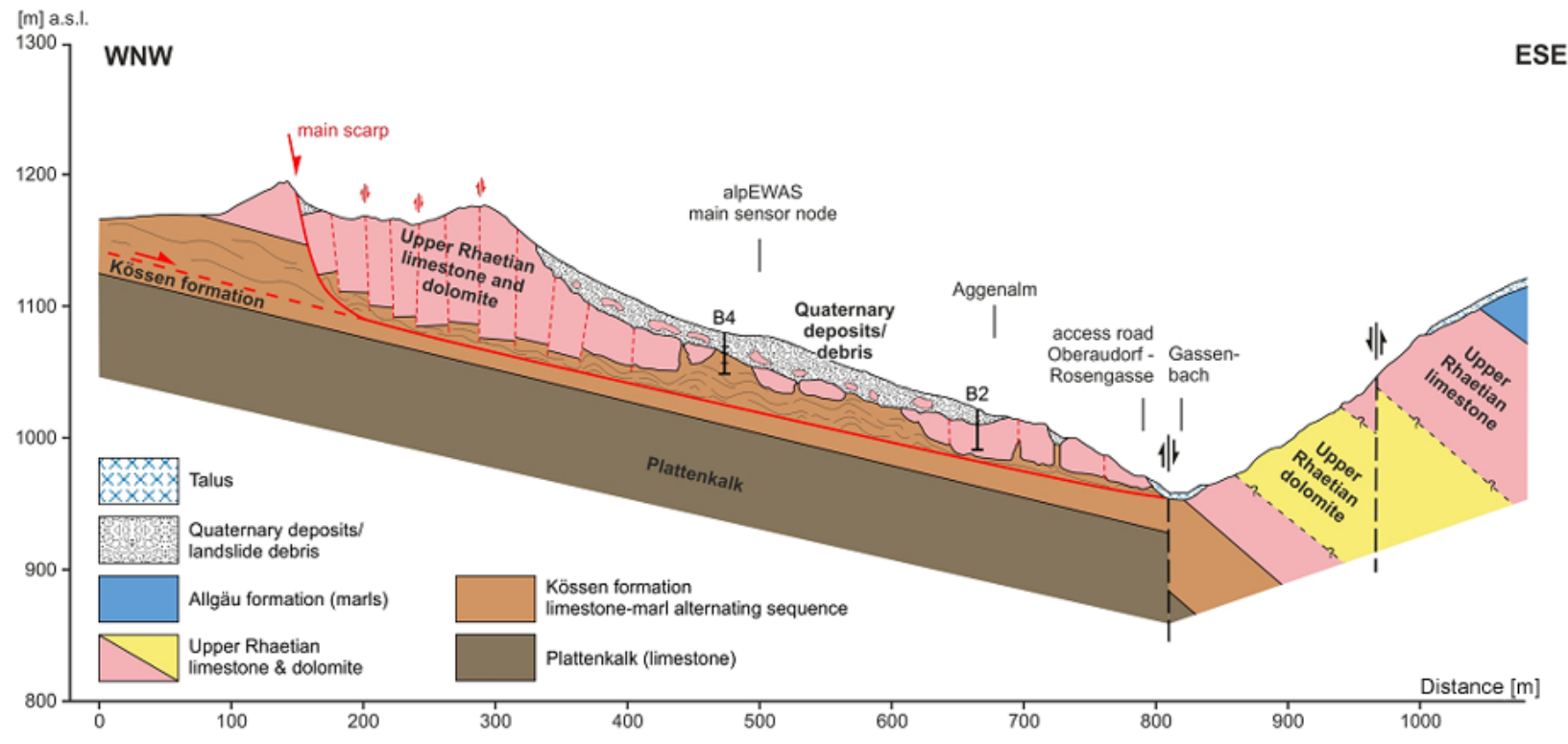

Figure 3. Geological profile of the Aggenalm landslide (Festl, 2014).

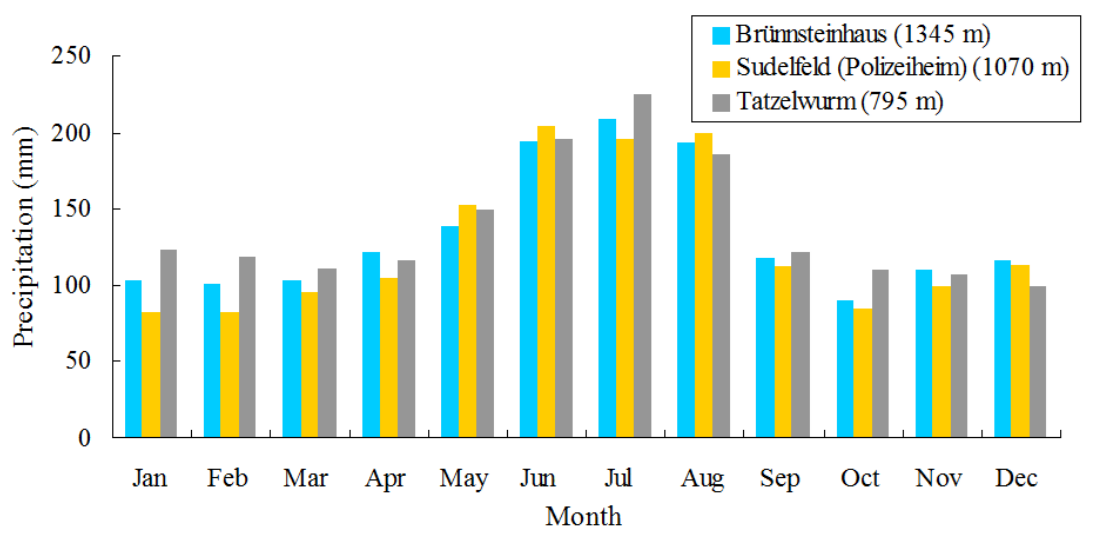

Figure 4. Mean monthly precipitation (1931-1960 and 1961-1990) for the Brünnsteinhaus, the Sudelfeld (Polizeiheim) and Tatzelwurm meteorological stations (data from Germany's National Meteorological Service, DWD).

pressure with real pore water pressure readings. In addition, a long-term consistency simulation of 2 years' PWP levels is compared to the 2 years of monitoring data of PWP levels bridging the data gaps.

\subsection{The modified tank model including snowmelt and infiltration}

Figure 5 demonstrates the successive changes from the original tank model (Ishihara and Kobatake, 1979; Michiue, 1985; Ohtsu et al., 2003; Uchimura et al., 2010) to our modified model.
Figure 5a shows the basic concept of the original tank model, the daily change in the groundwater table height $h_{i+1}-h_{i}$ is

$h_{i+1}-h_{i}=R_{i}-q_{i}$,

where $R_{i}$ is the rainfall and $q_{i}$ is the drainage of the $i$ th day. $h_{i}$ is groundwater table height the $i$ th day.

If groundwater supply illustrated in Fig. $5 \mathrm{~b}$ is incorporated in the tank model, the daily change in groundwater table height $h_{i+1}-h_{i}$ is

$h_{i+1}-h_{i}=R_{i}-\left(q_{i}-g_{i}\right)$,

where $g_{i}$ is groundwater supply of the $i$ th day from the upper slope. 


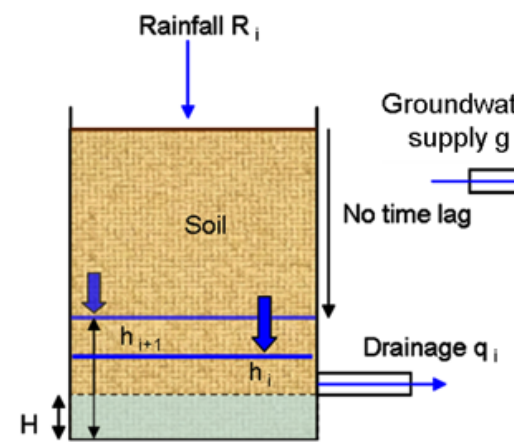

(a)

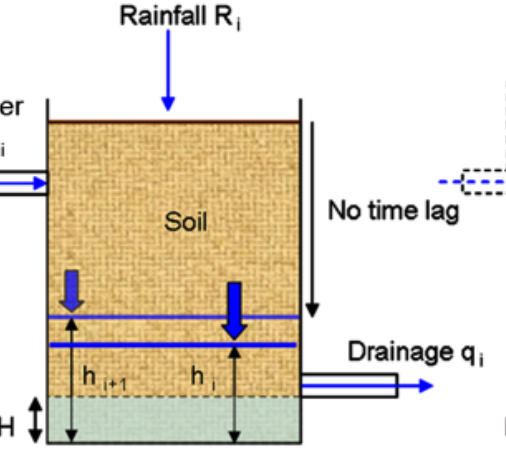

(b)

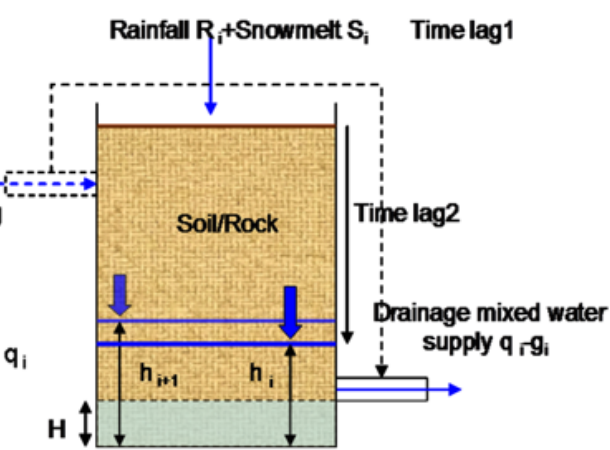

(c)

Figure 5. Design of the modified tank model. (a) Original tank model considering the vertical infiltration and drainage affecting the water table. (b) Improved model considering both vertical infiltration and horizontal water flow. (c) Modified tank model including water supply and two time lags (snowmelt and infiltration).

Incorporating snowmelt, Eq. (3) should be written as

$h_{i+1}-h_{i}=R_{i}+S_{i}-\left(q_{i}-g_{i}\right)$,

where $S_{i}$ is the snowmelt of the $i$ th day.

Snow accumulation and snowmelt produces our time lag 1 controlled by ambient temperature. Long infiltration paths which can take 1 or more days to reach the water table in deep-seated landslide masses cause time lag 2 (Fig. 5c). The infiltration in $i$ th day affects not only the groundwater table of the $i$ th day but also the groundwater table over the following $n$ days if time lag 2 is more than 1 day. $R_{i}$ and $S_{i}$ are divided into $n$ parts $\left(R_{i}=\sum_{n=1}^{N} R_{i}^{(n)}\right.$ and $S_{i}=$ $\left.\sum_{n=1}^{N} S_{i}^{(n)}, i, n \geq 1\right)$. Each component $\left(R_{i}^{(n)}\right.$ and $\left.S_{i}^{(n)}\right)$ contributes to daily changes in the groundwater table $\left(h_{i+n}-\right.$ $\left.h_{i+n-1}\right)$. For a time lag of 2 days, the total daily variations $\left(h_{i+2}-h_{i+1}\right)$ in response to rainfall and snowmelt can be described by $R_{i-1}^{(3)}+S_{i-1}^{(3)}, R_{i}^{(2)}+S_{i}^{(2)}$ and $R_{i+1}^{(1)}+S_{i+1}^{(1)}$, considering that the groundwater table in $i+1$ th day is affected not only by the infiltration today but also by the infiltration of the previous 2 days (Fig. 6).

The antecedent precipitation index (API) can reduce this time lag 2 by estimating the current water content of the ground affected by previous precipitation (Chow, 1964). This is equivalent to the infiltration calculations of some authors (Suzuki and Kobashi, 1981; Matsuura et al., 2003, 2008) who define equivalent infiltration as

$$
\begin{aligned}
& \mathrm{ER}_{i}+\mathrm{ES}_{i}=(0.5)^{1 / M} R_{i}+(0.5)^{1 / M} \mathrm{ER}_{i-1}+(0.5)^{1 / M} S_{i} \\
& +(0.5)^{1 / M} \mathrm{ES}_{i-1},
\end{aligned}
$$

where $\mathrm{ER}_{i-1}$ and $\mathrm{ES}_{i-1}$ represent the equivalent rainfall and snowmelt of $i-1$ th days, respectively; $R_{i}$ and $S_{i}$ mean the rainfall and snowmelt of $i$ th day; $(0.5)^{M}$ means the effect of infiltration reduces to $50 \%$ in $M$ days, where $M$ is determined by field observations. The whole modified tank model with an equivalent infiltration method could substitute both time lag 1 , by integrating snow accumulation and snowmelt (Sect. 2.4), and time lag 2. The relationship between infiltration and water table is often proportional in slopes (Matsuura et al., 2008; Schulz et al., 2009; Thuro et al., 2010; Yin et al., 2010). Therefore, the conceptual equation of changed water table should be

$\Delta h_{i}=h_{i+1}-h_{i}=\frac{\alpha}{n}\left(\mathrm{ER}_{i}+\mathrm{ES}_{i}\right)-\left(q_{i}-g_{i}\right)$,

where $\alpha$ is a proportional coefficient ( $\alpha$ is 1 for only the ideal tank model) and $n$ is the average porosity of slope mass. Hereby, "pore water pressure" is mainly positive pressure induced by groundwater table height. It does not refer to perched water or negative pore water pressures.

Thus, PWP can be linearly correlated to groundwater levels as Eq. (11).

$\Delta \mathrm{PWP}_{i}=\frac{\alpha g^{\prime}}{n}\left(\mathrm{ER}_{i}+\mathrm{ES}_{i}\right)-\Delta \mathrm{PWP}_{(g+q) i}$,

where $g^{\prime}$ is acceleration of gravity, $\Delta \mathrm{PWP}_{(g+q) i}$ is the PWP change by subsurface inflows and outflows on the $i$ th day. This allows us to evaluate changes in PWP resulting from infiltration, drainage and groundwater supply. The major part of pore water pressure is static pressure induced by water table height. Minor components are seepage force and the difference of pressures in the available pore space over drier and wetter periods. Since the tank model is a "grey box model", we do not know the exact proportions of static pressure, seepage pressure and pressure dynamics in pore space, all three of which are included in our equivalent pore water pressure.

$$
\Delta \mathrm{PWP}_{i}=\alpha^{\prime}\left(\mathrm{ER}_{i}+\mathrm{ES}_{i}\right)-\Delta \mathrm{PWP}_{(g+q) i}
$$

In Eq. (12), $\alpha^{\prime}$ replaces $\frac{\alpha g}{n}$ to simplify the model. The workflow chart of our modified tank model for change of $\mathrm{PWP}_{i}$ is indicated in Fig. 7. 


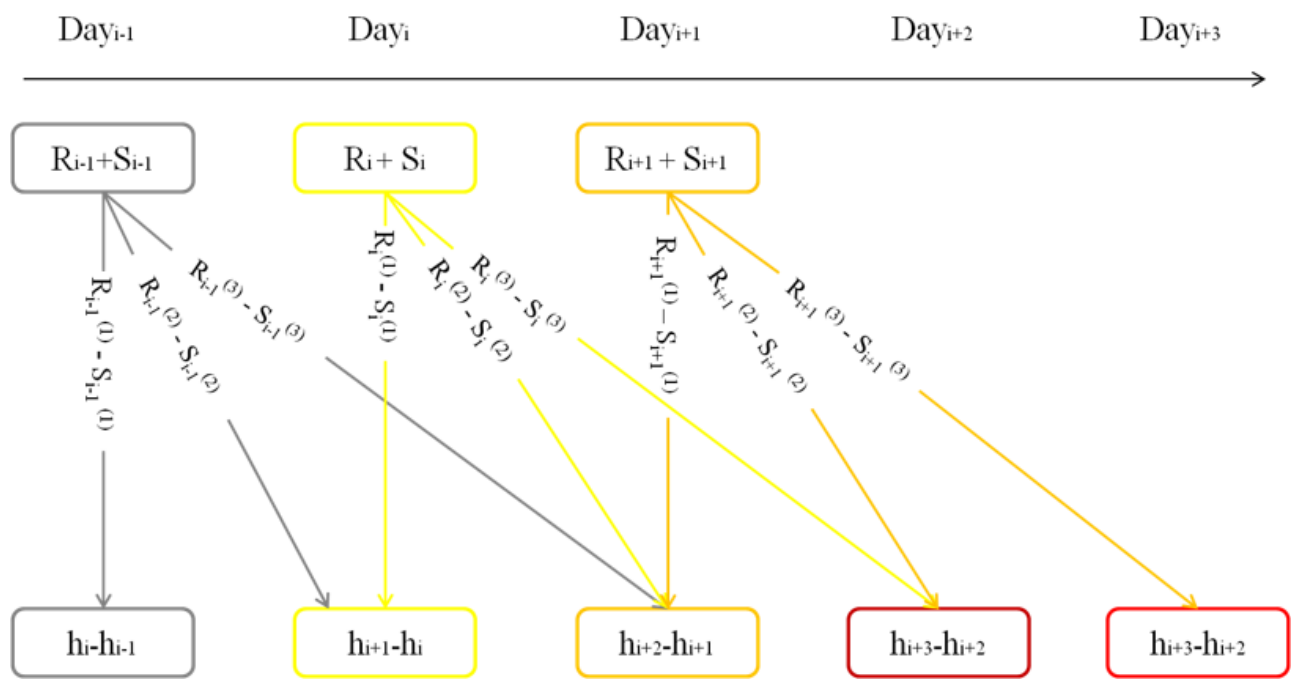

Figure 6. Schematic diagram of water infiltration from the surface to the groundwater table for a time lag 2 of 2 days.

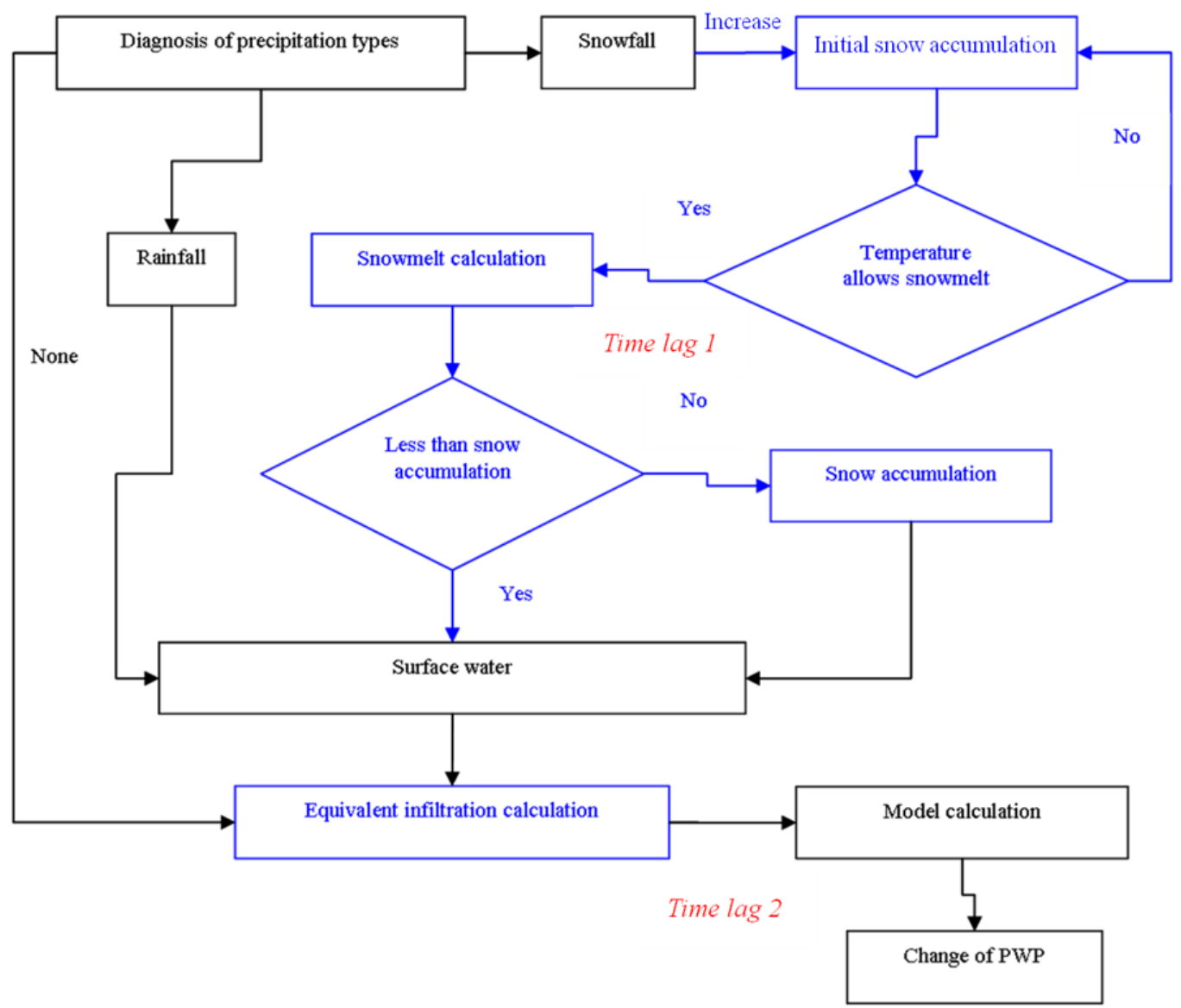

Figure 7. The workflow chart of the modified tank model with respect to the original model. Time lags from snow accumulation, snowmelt and infiltration are highlighted in blue. 


\subsection{Model assumptions to simplify slope hydrology}

We assume that Quaternary deposits control the hydraulic properties of the tank model (tank interior with soil/rock in Fig. 5). The fractured limestone and dolomite control the water flow from higher to lower elevations (groundwater inflow and drainage in Fig. 5). The marly Kössen beds are treated as impermeable layers (thin, low porosity and high normal stress above). As this is a regional groundwater table estimation, we can use the modified tank model to simulate the groundwater table changes induced by precipitation. We ignore surface run-off flow resulting from snowmelt and heavy rainfall as (1) the slope angle is less than $15^{\circ}$, (2) the cumulative snowpack is no more than $70 \mathrm{~cm}$ during monitoring days and (3) the infiltration rate of slope in Quaternary deposits and on carbonates is relatively high. We ignore freezing effects on infiltration as (1) ground sealing by freezing is presumably not an issue since the bottom temperature of snow is next to $0{ }^{\circ} \mathrm{C}$ underlain by a warmer subsoil in addition to high permeable subsoil. (2) Snow accumulation during winters and winter rainfall precipitation prevent effective cooling of ground. Due to the all-year humid climate, the rapid drainage of water in the permeable underground and the deep-seated nature of the slope movement, we did not explicitly consider evapotranspiration.

\subsection{Determining change in pore water pressure in the modified tank model}

In order to determine an appropriate value of $\alpha^{\prime}$ for the Aggenalm landslide, we use 13 months of training data to fit equivalent rainfall and $\triangle \mathrm{PWP}$ (Fig. 8).

The linear relationship between daily change of pore water pressure $\left(\Delta \mathrm{PWP}_{i}\right)$ and daily equivalent rainfall $\left(\mathrm{ER}_{i}\right)$ for absolute data is shown in Fig. 8a. We then aggregate bins of mean values of daily change of pore water pressure for daily equivalent rainfall (Fig. 8b) to replace data of the same width (Fig. 8a) (Freedman et al., 1998). The result shows change of $\mathrm{PWP}_{i}$ as

$\Delta \mathrm{PWP}_{i}=\alpha^{\prime} \mathrm{ER}_{i}-\beta$,

where $\alpha^{\prime}\left(\mathrm{kPamm}^{-1}\right)$ is 0.103 and relates rainfall to pore pressure increase and $\beta(0.3524)(\mathrm{kPa})$ is the average daily decrease of pore water pressure by drainage. This means that on a day without infiltration by snowmelt and rainfall the pore water pressure drops by $0.35 \mathrm{kPa}$, i.e. the water column drops by $35 \mathrm{~mm}$. According to the original tank theory the decrease of pore water pressure rate depends on the current pore water pressure (Michiue, 1985; Ohtsu et al., 2003; Takahashi, 2004; Takahashi et al., 2008; Xiong et al., 2009; Uchimura et al., 2010). In reality, the relationship can only be calculated by monitoring an extended period without infiltration. As shown in Fig. 9a, the observation of PWP is within 48 days without rainfall input where drainage is still combined with groundwater supply. Almost every landslide has a basic water table or minimum water table (here starts at $\sim 29 \mathrm{kPa}$ ). It means the "drainage position" is higher than the "bedrock" (for other cases see Matsuura et al., 2008; Schulz et al., 2009; Yin et al., 2010). The relation between $\mathrm{PWP}_{i+1}$ and $\mathrm{PWP}_{i}$ without rainfall infiltration is shown in Fig. $9 \mathrm{~b}$ and Eq. (14).

$\mathrm{PWP}_{i+1}=a^{\prime} \mathrm{PWP}_{i}+b$,

where $a^{\prime}$ and $b$ are fitted coefficients.

Thus, $\Delta \mathrm{PWP}_{i}$ calculation could be rewritten as

$$
\Delta \mathrm{PWP}_{i}=\alpha^{\prime}\left(\mathrm{ER}_{i}+\mathrm{ES}_{i}\right)+\left(\left(a^{\prime}-1\right) \mathrm{PWP}_{i}+b\right) .
$$

\subsection{Snowmelt calculations in modified tank model}

\subsubsection{Diagnosis of precipitation types}

A threshold temperature under which the precipitation falls as snow is a key factor for a snow accumulation model. However, diagnosis of precipitation is difficult, and there are no parameters with which the type of precipitation can be accurately determined (Wagner, 1957; Koolwine, 1975; Bocchieri, 1980; Czys et al., 1996; Ahrens, 2007). The most common approach is to derive statistical relationships between some predictors and different precipitation types (Bourgouin, 2000). We select a statistical model (empirical formula) based on hundreds of observation samples in Wajima, Japan, between 1975 and 1978 to estimate precipitation types (Matsuo and Sasyo, 1981). The threshold of relative humidity calculated by $T_{\mathrm{d}}$ (daily average temperature) is as follows:

$\mathrm{RH}_{t}=124.9 e^{-0.0698 T_{\mathrm{d}}}$.

If the real relative humidity $\mathrm{RH}$ is smaller than $\mathrm{RH}_{t}$, the precipitation is usually snowfall (Häggmark and Ivarsson, 1997).

\subsubsection{Snowmelt model}

One of the most popular methods employed to forecast snowmelt is to correlate air temperature with snowmelt data. Such a relation was first used for an alpine glacier by Finsterwalder and Schunk (1887) and has since then been extensively applied and further refined (Kustas et al., 1994; Rango and Martinec, 1995; Hock, 1999, 2003). Recently, the most widely accepted temperature index model is that of Hock (2003). The approach of daily melt assumes the form

$M^{\prime}=f_{m}\left(T_{\mathrm{d}}-T_{0}\right)$,

where $T_{0}$ is a threshold temperature beyond which melt is assumed to occur (typically $0{ }^{\circ} \mathrm{C}$ ), and $f_{m}$ is a degree-day factor. We apply a widely used empirical $f_{m}$ (e.g. Gottlieb, 1980; Lang, 1986; Braun et al., 1994; Hock, 2003), which reflects the canopy cover in percent, beginning time of 

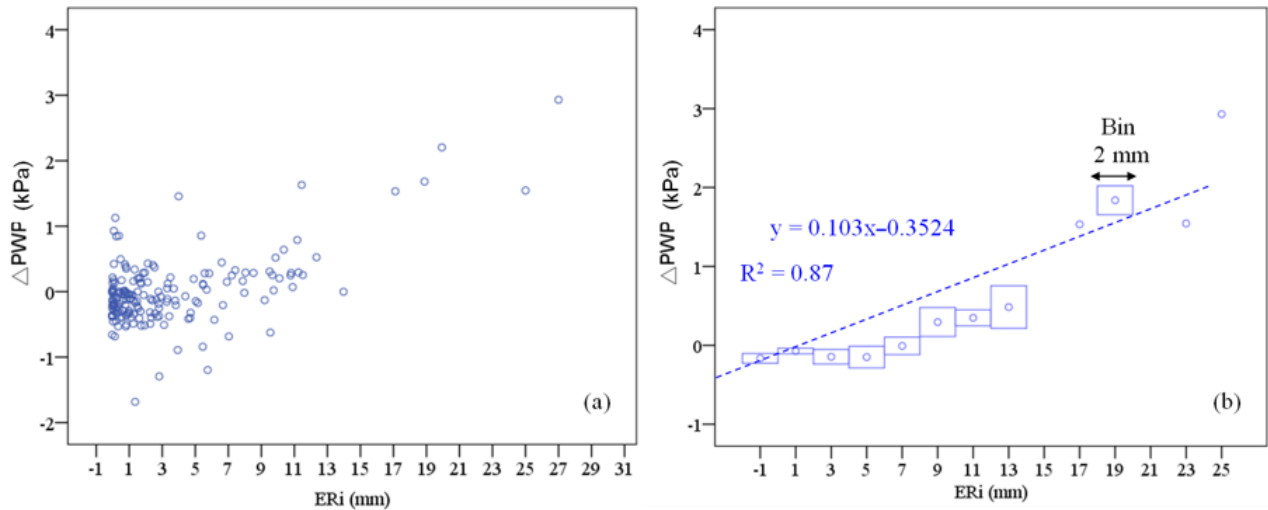

Figure 8. (a) Daily equivalent rainfall $\left(\mathrm{ER}_{i}\right)$ vs. daily change of pore water pressure $\left(\mathrm{PWP}_{i}\right)$ in absolute values for 13 months $($ September 2009-February 2010 and May-November 2010). (b) $\mathrm{PWP}_{i}$ has been aggregated in bins of mean values for discrete steps of daily equivalent rainfall (mean +1 sigma error).
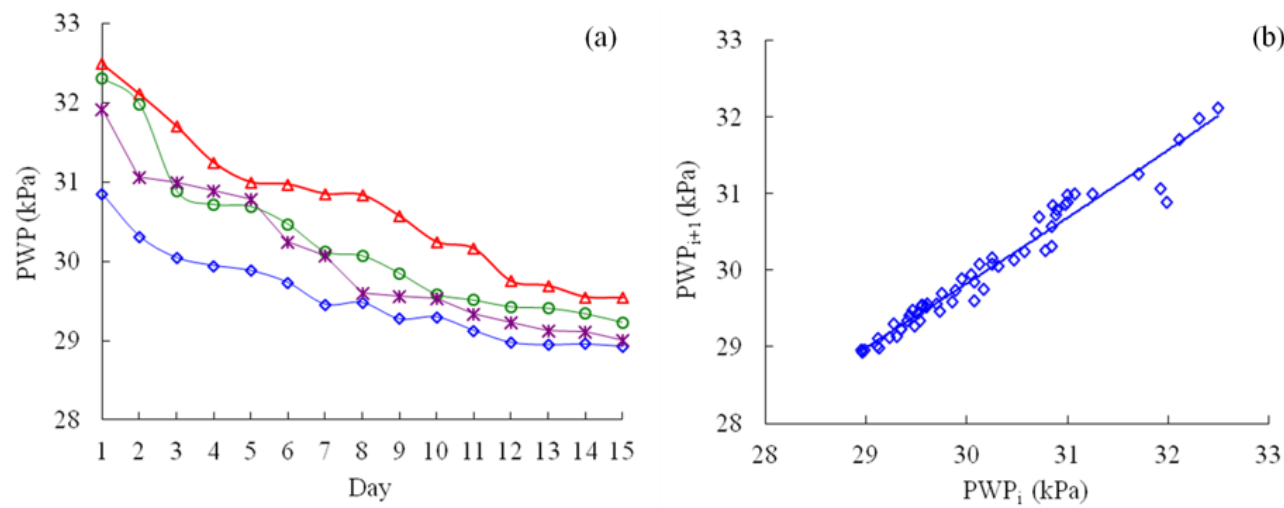

Figure 9. (a) Observation of PWP vs. time for four 15-day-long periods without rainfall or snowmelt (number of samples: $n=48$ ). (b) PWP vs. $\mathrm{PWP}_{i+1}(i$ th day of PWP correlates to $i+1$ th day of PWP for four 15-day-long periods without rainfall or snowmelt (number of samples: $n=48)$.

snowmelt, etc. In this case, we think that the best strategy is the usage of the empirical formula, since $>80 \%$ of the landslides are not forest covered and the forest cover only applies to the upper highly fractured limestone portion that is at a significant distance from the pore pressure measurement. Here, the degree-day factor is calculated by the empirical formula as follows:

$f_{m}=2.92-0.0164 F$

where $F$ is canopy covers of landslide area in percent (Esko, 1980).

\section{Results}

\subsection{Performance of modified tank model in heavy rainfall season}

As shown in Fig. 10, our modified tank model and original tank model considering no time lag are used to estimate the change of PWP in summer. Both the original and modified tank model do reasonable estimate changes in PWP during summer. The original model, however, generally overestimates the PWP curve. The modified model matches the measurement curve better due to the infiltration time lag 2 .

\subsection{Performance of modified tank model in snowmelt season}

The original model without snow accumulation and snowmelt failed to accurately estimate PWP during spring, as the change of PWP without time lag 1 caused by the original model to overestimate PWP from days 12 to 33 (Fig. 11). The modified tank model better reflects the peak of snowmelt (days 33-37) and matches the measurement curve well in consideration of time lag 1 . The deviation derives from the naturally limited accuracy of snow accumulation and snowmelt models. 


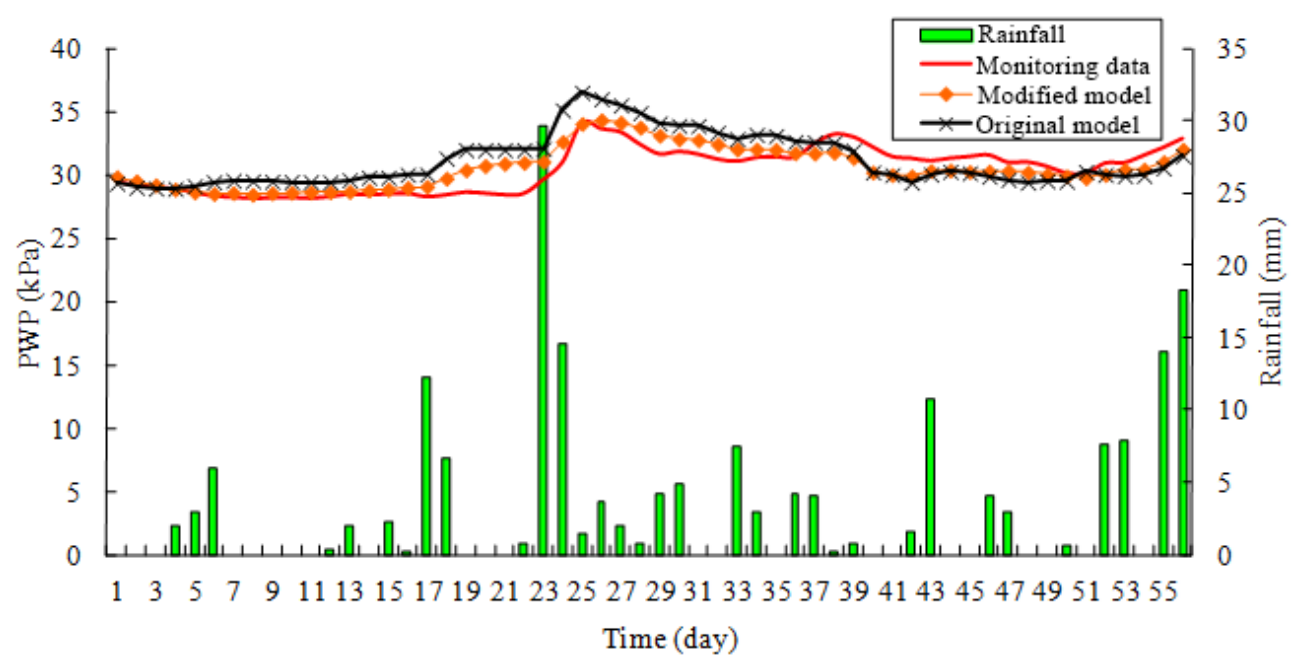

Figure 10. Estimation of the PWP using the original tank model and our modified tank model (snowmelt + time lag $1+2$ ) during summer (7 July-31 August 2009).

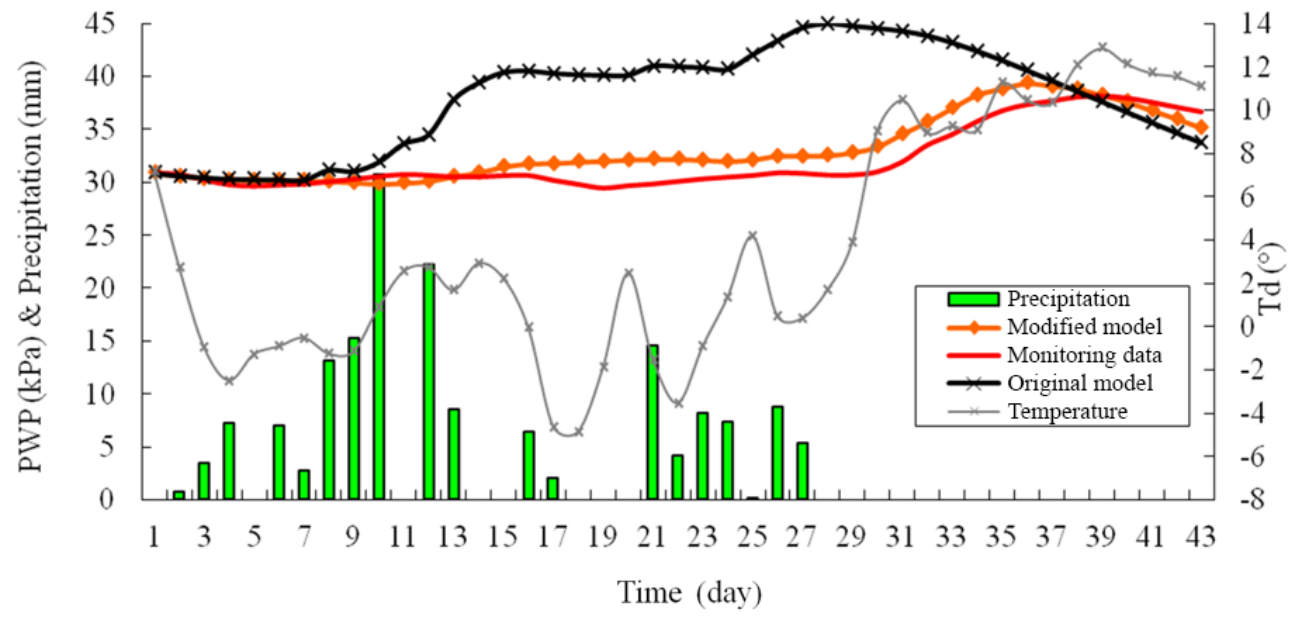

Figure 11. Estimation of the change of PWP using the original tank model and our modified tank model (snowmelt + time lag $1+2)$ in the snowmelt season (4 March-15 April 2009).

Figure 12 indicates evaluation index of original and modified tank model including correlation, root mean square error (RMSE) and relative error.

As shown in Fig. 13, modified tank model simulated the PWP levels in whole monitoring period.

\section{Discussion}

In order to evaluate the performance of the modified tank model with respect to heavy rainfall and snowmelt, we introduce the standard Nash-Sutcliffe (1970) efficiency (NSE), which is the most widely used criterion for calibration and evaluation of hydrological models with observed data. NSE is dimensionless and is scaled onto the interval [inf. to 1.0]. NSE is taken to be the "mean of the observations" (Murphy,
1988) and if NSE is smaller than 0, the model is no better than using the observed mean as a predictor.

\subsection{Performance of modified tank model in heavy rainfall season}

The modified tank model describes the fluctuation of PWP reasonably well, especially during heavy rainfall days such as days 23 to 26 ( $43 \mathrm{~mm}$ ) and days 51 to 55 (45 mm) (Fig. 10). The relative errors in Fig. 12a are less than 3 and $4 \%$ during these days. Dry periods (such as days 2-7 and 17-21) agree with PWP measurement, with a relative error of 2-9\% as shown in Fig. 12a. The low water content of the landslide materials during the dry season appears to reduce the infiltration rates (Fredlund and Xing, 1994; Schaap and Van Genuchten, 2006). And PWP levels increase very slowly or 


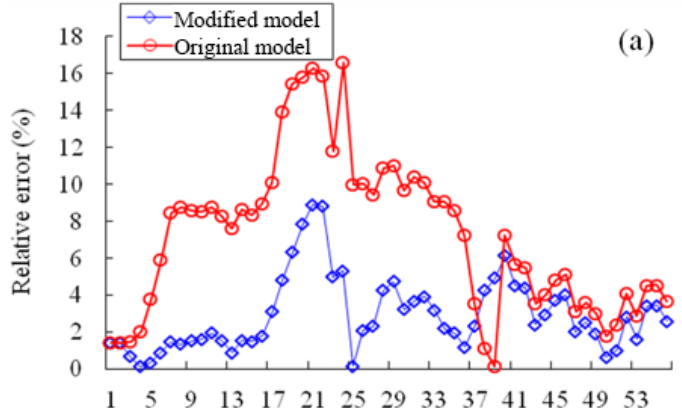

Time (day)

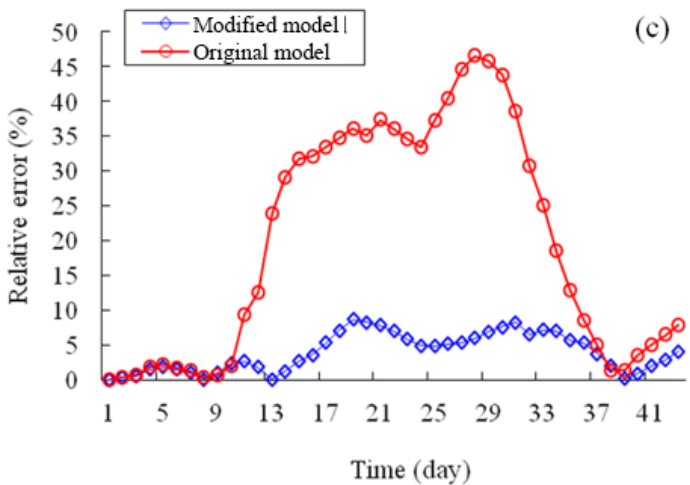

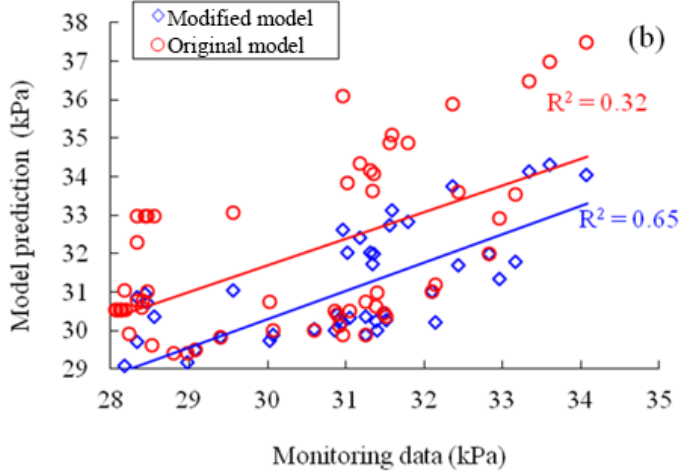

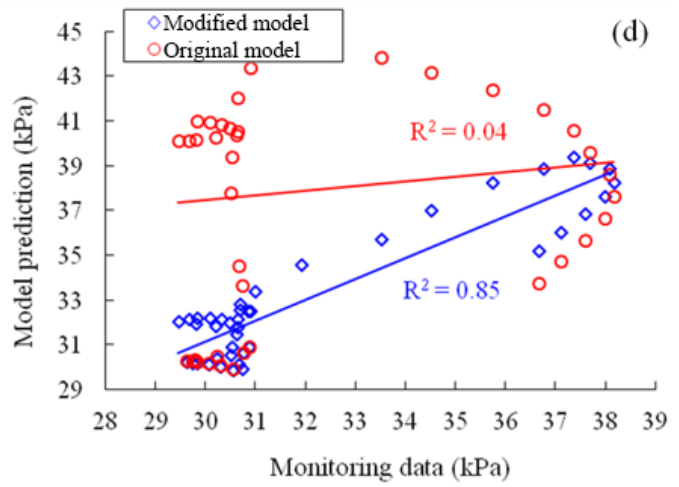

Figure 12. Evaluation of original and modified tank model. (a) Correlation between measurements and original/modified tank model during a 54-day rainfall period $(n=54)$. Root mean square errors (RMSE) for the original and modified models are 1.9 and 0.97 , respectively. (b) Correlation between measurements and original/modified tank model in snowmelt period $(n=47)$. The RMSE approaches 5.4 and 1.3 for the original model and the modified model. (c) Relative error of original and modified tank model in summer $(n=54)$. (d) Relative error of original and modified tank model during spring $(n=47)$.

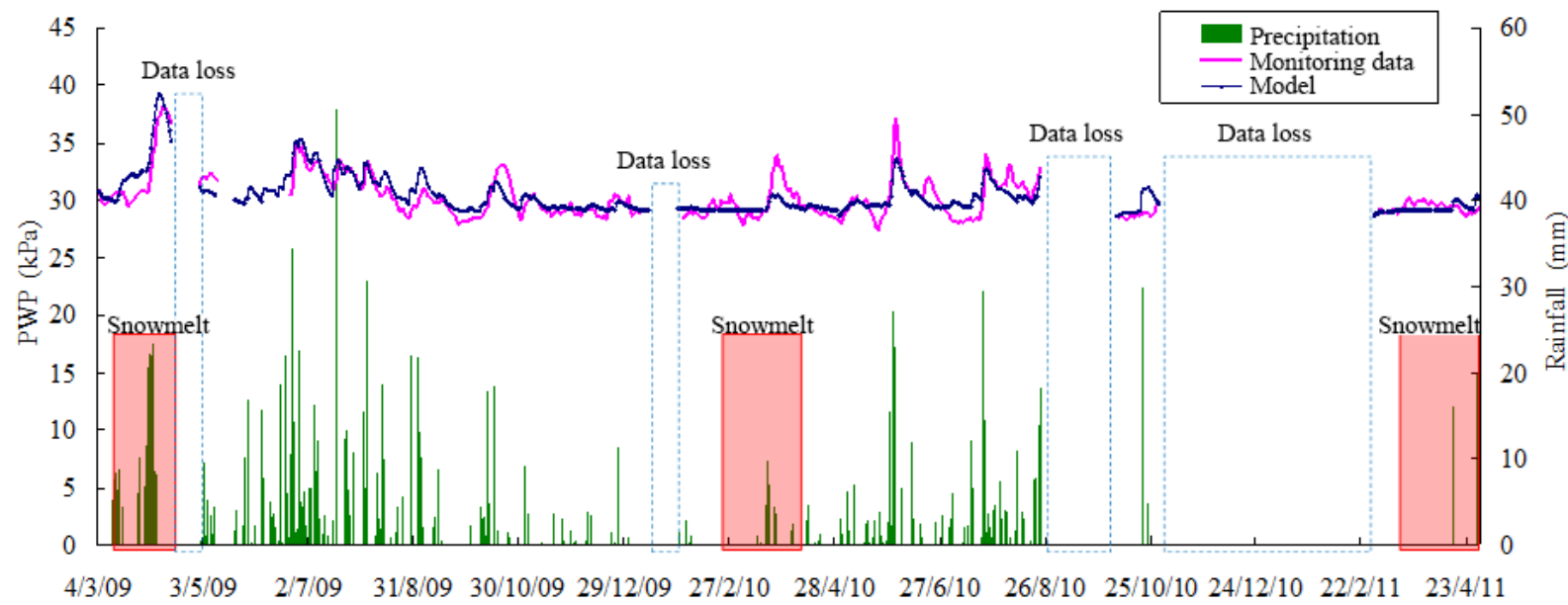

Figure 13. Long-term consistency simulation of PWP using the modified tank model throughout the entire monitoring period (4 March 200923 April 2011).

not at all during these periods. As a result, the relative error of our modified model is slightly higher than that during wetter intervals. Compared with the original model, our model better represents PWP monitoring data. Figure 10b indicates a higher linear correlation between measurements and modified tank model with 0.65 (RMSE: 0.97) than the original tank model with 0.29 (RMSE: 1.9). The NSEs of the original tank model and our modified tank model during the heave 
rainfall season are -0.09 and 0.63 , respectively. This means the standard original tank model is no better than the "mean of the observations" while our modified tank model has a significantly higher explanatory power.

\subsection{Performance of modified tank model in snowmelt season}

We found a better correlation between measurements and our modified tank model with 0.86 (RMSE: 0.97 ) than the original tank model in which all precipitation was assumed to be rainfall and snowmelt was not considered with 0.04 (RMSE: 5.4) during snowmelt period. It has to be pointed out that the snowmelt estimation is still not very precise, as the temperature index model is relatively simple (Garen and Marks, 2005; Herrero et al., 2009; Lakhankar et al., 2013). Also, we do not consider surface run-off due to the high permeability of surface deposits. Our modified tank model, however, provides a useful estimation of increased PWP in creeping landslide masses several tens of metres deep. The NSEs of the original tank model and modified tank model during the snowmelt season are -5.95 and 0.75 , respectively, which emphasizes the performance of the modified tank model.

\subsection{Highlights of our modified model}

Compared to the simple tank model, our modified tank model improves the prediction ability by introducing the equivalent infiltration method to reduce the infiltration time lags. Compared to the recent multi-tank model researches (Ohtsu et al., 2003; Takahashi, 2004; Takahashi et al., 2008; Xiong et al., 2009), our modified tank model does not require complicated algorithms and several observation boreholes to optimize the parameters. It is a straightforward approach. The model integrates the snow accumulation-snowmelt model, which is not considered in other tank model researches. We present a flexible approach since the model can simulate groundwater table at least 2 years continuously without obvious accumulative error, unlike permeability-based numerical models or optimization parameter-based models that need refreshment at times (Takahashi et al., 2008; Xiong et al., 2009).

\subsection{Drawbacks and limitations}

The naturally inevitable drawback for any "empirical model" is that it is physically not explicit. The presented model would need further adjustments for permafrost regions, with heavily frozen soils, for very steep slopes, with significant surface run-off and for very heterogeneous slopes, with complex fractured rock masses. However, it seems well suited for large mountain landslides on moderately inclined slopes in alpine conditions with significant snow accumulations.

\section{Conclusions}

Pore water pressure is one of the important dynamic factors in deep-seated slope destabilization and our modified tank model could help to anticipate critical states of deepseated landslide stability a few days in advance by predicting changes in pore water pressure. In this paper, we propose a modified tank model for the estimation of increased pore water pressure induced by rainfall or snowmelt events in deep-seated landslides. Compared to the original tank model, we simulate the fluctuation of PWP more accurately by reducing the time lag effects induced by snow accumulation, snowmelt and infiltration into deep-seated landslides. In this modified model, a statistical method based on temperature and humidity controls precipitation type and a snowmelt model based on the temperature index method governs melting. Here we demonstrate a modified tank model for deep-seated landslides which includes snow accumulation, snowmelt and infiltration effects and can effectively predict changes in pore water pressure in alpine environments.

Data availability. All data are available upon request from the corresponding author. 


\section{Appendix A: Nomenclature}

$\alpha \quad$ related coefficient between equivalent infiltration and increased groundwater table, 1

$\alpha^{\prime} \quad$ related coefficient between equivalent infiltration and increased pore water pressure, $\mathrm{kPa} \mathrm{mm}^{-1}$

$\beta \quad$ average value of pore water pressure changed by drainage and groundwater supply, $\mathrm{kPa}$

$a$ parameter for the relation between $h_{i}$ and $q_{i}, 1$

$a^{\prime} \quad$ related coefficient between pore water pressure of $i$ th day and $i+1$ th day without infiltration, 1

a1 parameter for the relation between $\mathrm{h} 1_{i}$ and $\mathrm{d} 1_{i}, 1$

a2 parameter for the relation between $\mathrm{h} 2{ }_{i}$ and $\mathrm{d} 2_{i}, 1$

a3 parameter for the relation between $\mathrm{h} 3_{i}$ and $\mathrm{d} 3_{i}, 1$

$b \quad$ related coefficient between pore water pressure of $i$ th day and $i+1$ th day without infiltration, 1

$\mathrm{d} 1_{i} \quad$ infiltration of the $i$ th day in middle soil layer, $\mathrm{mm}$

$\mathrm{d} 2_{i} \quad$ infiltration of the $i$ th day in lower soil layer, $\mathrm{mm}$

$\mathrm{d} 3_{i} \quad$ drainage of $i$ th day in lower soil layer, $\mathrm{mm}$

$\mathrm{ER}_{i} \quad$ equivalent rainfall of $i$ th day, mm $\quad R_{i}^{(n)}$

$\mathrm{ES}_{i} \quad$ equivalent snowmelt of $i$ th day, mm $\quad \mathrm{RH}$

$f_{m}$ degree-day factor for snowmelt rate, $\mathrm{RH}_{t}$ $\mathrm{mm}^{\circ} \mathrm{C}^{-1}$

$F \quad$ canopy covers percent, 1

$g_{i} \quad$ groundwater supply of $i$ th day, mm

$g^{\prime} \quad$ acceleration of gravity, $\mathrm{m} \mathrm{s}^{-2}$

$S_{i}^{(n)}$

$h_{i} \quad$ groundwater table height the $i$ th day, $\quad S_{i}$ $\mathrm{mm}$

$h_{i+1}$ groundwater table height the $i+T_{\mathrm{d}}$ 1 th day, $\mathrm{mm}$

$\mathrm{h} 1_{i} \quad$ water table level of the $i$ th day in higher soil layer, $\mathrm{mm}$
M

$R_{i}$

$\mathrm{h} 1_{i+1}$

$\mathrm{h} 2_{i}$

$\mathrm{h} 2_{i+1}$

$\mathrm{h} 3_{i}$

$\mathrm{h} 3_{i+1}$

H

$M^{\prime}$

$n$

$q_{i}$

$\mathrm{PWP}_{i}$

$\Delta \mathrm{PWP}_{(g+q) i}$

$\Delta \mathrm{PWP}_{i}$

$H_{t}$

$S_{i}^{(n)}$

$S_{i}$

$T_{\mathrm{d}}$

water table level of the $i+1$ th day in higher soil layer, $\mathrm{mm}$

water table level of the $i$ th day in middle soil layer, $\mathrm{mm}$

water table level of the $i+1$ th day in middle soil layer, $\mathrm{mm}$

water table level of the $i$ th day in lower soil layer, $\mathrm{mm}$ water table level of the $i+1$ th day in lower soil layer, $\mathrm{mm}$

base water table, $\mathrm{mm}$

daily snowmelt, $\mathrm{mm}$

average porosity of slope mass, 1

drainage of $i$ th day, mm

pore water pressure of $i$ th day, $\mathrm{kPa}$

PWP changed by drainage combined groundwater supply, $\mathrm{kPa}$

change of pore water pressure of $i$ th day, $\mathrm{kPa}$

part of rainfall of $i$ th day to changed pore water pressure of $i$ th day, mm relative humidity, 1

threshold of relative humidity, 1

time about effect of infiltration reducing to $50 \%, 1$

rainfall of $i$ th day, mm

part of snowmelt of $i$ th day to changed pore water pressure of $i$ th day, $\mathrm{mm}$

rainfall of $i$ th day, mm

daily average temperature, ${ }^{\circ} \mathrm{C}$ 
Competing interests. The authors declare that they have no conflict of interest.

Acknowledgements. The authors thank the support from the China Scholarship Council and monitoring data from project "alpEWAS", especially John Singer for providing pore pressure data and supervising earlier stages of this project.

This work was supported by the German Research

Foundation (DFG) and the Technische Universität

München within the funding programme

Open Access Publishing.

Edited by: Thomas Glade

Reviewed by: two anonymous referees

\section{References}

Abebe, N. A., Ogden, F. L., and Pradhan, N. R.: Sensitivity and uncertainty analysis of the conceptual HBV rainfall-runoff model: implications for parameter estimation, J. Hydrol., 389, 301-310, 2010.

Agliardi, F., Crosta, G. B., Zanchi, A., and Ravazzi, C.: Onset and timing of deep-seated gravitational slope deformations in the eastern Alps, Italy, Geomorphology, 103, 113-129, 2009.

Ahrens, C. D.: Meteorology Today: an Introduction to Weather, Climate, and the Environment, Cengage Learning, California, USA, 2007.

Angeli, M. G., Gasparetto, P., Silano, S., and Tonnetti, G.: An automatic recording system to detect critical stability conditions in slopes, in: Proc. of the 5th ISL, Lausanne, 375-378, 1988.

Angeli, M. G., Gasparetto, P., Menotti, R. M., Pasuto, A., and Silvano, S.: A visco-plastic model for slope analysis applied to a mudslide in Cortina d'Ampezzo, Italy, Q. J. Eng. Geol. Hydroge., 29, 233-240, 1996.

Angeli, M. G., Gasparetto, P., and Bromhead, E.: Strength-regain mechanisms in intermittently moving landslides, in: Proceedings of the 9th International Symposium on Landslides, Rio de Janeiro, Taylor and Francis, London, 689-696, 2004.

Bocchieri, J. R.: The objective use of upper air sounding to specify precipitation type, Mon. Weather Rev., 108, 596-603, 1980.

Bourgouin, P.: A method to determine precipitation types, Weather Forecast., 15, 583-592, 2000.

Braun, L. N., Aellen, M., Funk, M., Hock, R., Rohrer, M. B., Steinegger, U., Kappenberger, G., and Müller-Lemans, H.: Measurement and simulation of high alpine water balance components in the Linth-Limmern head watershed (Northeastern Switzerland), Zeitschrift für Gletscherkunde und Glazialgeologie, 30, 161-185, 1994.

Bromhead, E. N.: Large landslides in London Clay at Herne Bay, Kent, Q. J. Eng. Geol. Hydroge., 11, 291-304, 1978.

Chen, L. and Young, M. H.: Green-Ampt infiltration model for sloping surfaces, Water Resour. Res., 42, W07420, https://doi.org/10.1029/2005WR004468, 2006.

Czys, R. R., Scott, R. W., Tang, K. C., Przybylinski, R. W., and Sabones, M. E.: A physically based, nondimensional parameter for discriminating between locations of freezing rain and ice pellets, Weather Forecast., 11, 591-598, 1996.

Esko, K.: On the values and variability of degree-day melting factor in Finland, Nord. Hydrol., 11, 235-242, 1980.

Faris, F. and Fathani, F.: A coupled hydrology/slope kinematics model for developing early warning criteria in the Kalitlaga Landslide, Banjarnegara, Indonesia, in: Progress of Geo-Disaster Mitigation Technology in Asia, Springer-Verlag Berlin Heidelberg, Berlin, Germany, 453-467, 2013.

Festl, J., Singer, J., and Thuro, K.: The Aggenalm landslide-first findings of the acquired monitoring data, in: Landslide and Engineered Slopes, Protecting Society Through Improved Understanding, edited by: Eberhardt, E., Froese, C., Turner, A. K. and Leroueil, S., Proceedings of the 11th International and 2nd North American Symposium on Landslides and Engineered Slopes, Banff, Canada 3-8 June 2012, Taylor \& Francis Group, London, 907-912, 2012.

Festl, J.: Analysis and evaluation of the geosensor network's data at the Aggenalm Landslide, Bayerischzell, Germany, $\mathrm{PhD}$ thesis, Technical University Munich, Munich, Germany, 2014.

Finsterwalder, S. and Schunk, H.: Der Suldenferner, Zeitschrift des Deutschen und Oesterreichischen Alpenvereins, 18, 72-89, 1887.

Fredlund, D. G. and Xing, A.: Equations for the soil-water characteristic curve, Can. Geotech. J., 31, 521-532, 1994.

Freedman, D., Pisani, R., and Purves, R.: Statistics, 4th Edn., W.W. Norton and Company, New York City, USA, 57-76, 1998.

Garen, D. C. and Marks, D.: Spatially distributed energy balance snowmelt modelling in a mountainous river basin: estimation of meteorological inputs and verification of model results, J. Hydrol., 315, 126-153, 2005.

Gottlieb, L.: Development and applications of a run off model for snow covered and glacierized basins, Nord. Hydrol., 11, 255284, 1980.

Gwinner, M. P.: Geologie der Alpen, Schweizerbart, Stuttgart, 477 pp., 1971.

Häggmark, L. and Ivarsson, K. I.: MESAN Mesoskalig analys, Sveriges meteorohoska och hydrologiska institute, SMHI RMK Nr. 75, 21-28, 1997.

Herrero, J., Polo, M. J., Moñino, A., and Losada, M. A.: An energy balance snowmelt model in a Mediterranean site, J. Hydrol., 371, 98-107, 2009.

Hock, R.: A distributed temperature-index ice- and snowmelt model including potential direct solar radiation, J. Glaciol., 45, 101$111,1999$.

Hock, R.: Temperature index melt modelling in mountain areas, J. Hydrol., 282, 104-115, 2003.

Hong, Y., Hiura, H., Shino, K., Sassa, K., and Fukuoka, H.: Quantitative assessment of the influence of heavy rainfall on a crystalline schist landslide by monitoring system - a case study of the Zentoku landslide, Japan, Landslides, 2, 31-41, 2005.

Ishihara, Y. and Kobatake, S.: Runoff model for flood forecasting, Bulletin of the Disaster Prevention Research Institute, 29, 27-43, 1979.

Iverson, R. M.: Landslide triggering by rain infiltration, Water Resour. Res., 36, 1897-1910, 2000.

Kustas, W. P., Rango, A., and Uijlenhoet, R.: A simple energy budget algorithm for the snowmelt runoff model, Water Resour. Res. 30, 1515-1527, 1994. 
Koolwine, T.: Freezing rain, MS thesis, Dept. of Physics, University of Toronto, Toronto, Canada, 92 pp., 1975.

Lakhankar, T. Y., Muñoz, J., Romanov, P., Powell, A. M., Krakauer, N. Y., Rossow, W. B., and Khanbilvardi, R. M.: CREST-Snow Field Experiment: analysis of snowpack properties using multifrequency microwave remote sensing data, Hydrol. Earth Syst. Sci., 17, 783-793, https://doi.org/10.5194/hess17-783-2013, 2013.

Lang, H.: Forecasting meltwater runoff from snow-covered areas and from glacier basins, in: River Flow Modelling and Forecasting, edited by: Kraijenhoff, D. A. and Moll, J. R., D. Reidel, Springer Netherlands, 99-127, 1986.

Lupini, J. F., Skinner, A. E., and Vaughn, P. R.: The drained residual strength of cohesive soils, Geotechnique, 31, 181-213, 1981.

Madritsch, H. and Millen, B. M. J.: Hydrogeologic evidence for a continuous basal shear zone within a deep-seated gravitational slope deformation (Eastern Alps, Tyrol, Austria), Landslides, 4, 149-162, 2007.

Matsuo, T. and Sasyo, Y.: Non-melting phenomena of snowflakes observed in sub saturated air below freezing level, J. Meteorol. Soc. Jpn., 59, 26-32, 1981.

Matsuura, S., Asano, S., Okamoto, T., and Takeuchi, Y.: Characteristics of the displacement of a landslide with shallow sliding surface in a heavy snow district of Japan, Eng. Geol., 69, 15-35, 2003.

Matsuura, S., Asano, S., and Okamoto, T.: Relationship between rain and/or meltwater, pore-water pressure and displacement of a reactivated landslide, Eng. Geol., 101, 49-59, 2008.

Mayer, K., Müller-Koch, K., and von Poschinger, A.: Dealing with landslide hazards in the Bavarian Alps[C], in: Proceedings of the 1st European conference on landslides, Prague, Balkema, Rotterdam, 417-421, 2002.

Michiue, M.: A method for predicting slope failures on cliff and mountain due to heavy rain, Natural Disaster Science, 7, 1-12, 1985.

Murphy, A.: Skill scores based on the mean square error and their relationships to the correlation coefficient, Mon. Weather Rev., 116, 2417-2424, 1988.

Nash, J. E. and Sutcliffe, J. V.: River flow forecasting through, Part I, a conceptual models discussion of principles, J. Hydrol., 10, 282-290, 1970.

Nickmann, M., Spaun, G., and Thuro, K.: Engineering geological classification of weak rocks, in: Proc. of the 10th International IAEG Congress, Nottingham, UK, 6 September 2006.

Nieuwenhuis, J. D.: Variations in the Stability and Displacements of a Shallow Seasonal Landslide in Varved Clays, $\mathrm{PhD}$ thesis, University Utrecht, The Netherlands Balkema, Rotterdam, 1991.

Nishii, R. and Matsuoka, N.: Monitoring rapid head scarp movement in an alpine rockslide, Eng. Geol., 115, 49-57, 2010.

Ohtsu, H., Janrungautai, S., and Takahashi, K.: A study on the slope risk evaluation due to rainfall using the simplified storage tank model, in: Proceeding of the 2nd Southeast Asia Workshop on Rock Engineering, Bangkok, Thailand, 67-72, 2003.

Picarelli, L.: Considerations about the mechanics of slow active landslides in clay, Progress in Landslide Science, in: edited by: Sassa, K., Fukuoka, H., Wang, F., and Wang, G., 27-57, 2007.

Rahardjo, H., Leong, E. C., and Rezaur, R, B.: Effect of antecedent rainfall on pore-water pressure distribution characteristics in residual soil slopes under tropical rainfall, Hydrol. Process., 22, 506-523, 2008.

Rahardjo, H., Nio, A. S., Leong, E. C., and Song, N. Y.: Effects of groundwater table position and soil properties on stability of slope during rainfall, J. Geotech. Geoenviron., 136, 1555-1564, 2010.

Rango, A. and Martinec, J.: Revisiting the degree-day method for snowmelt computations, J. Am. Water Resour. As., 31, 657-670, 1995.

Schaap, M. G. and Van Genuchten, M. T.: A modified Mualem-van Genuchten formulation for improved description of the hydraulic conductivity near saturation, Vadose Zone J., 5, 27-34, 2006.

Schmidt-thome, P.: Alpenraum, in: Erläuterungen geol, Kt. Bayern $1: 500000,2$ nd Edn., edited by: Bayerisches Geologisches Landesamt (LFU), Munich (LfU), Land Oberösterreich, Abteilung Grund- und Trinkwasserwirtschaft, 244-297, 1964.

Schulz, W. H., McKenna, J. P., Kibler, J. D., and Biavati, G.: Relations between hydrology and velocity of a continuously moving landslide - evidence of pore-pressure feedback regulating landslide motion?, Landslides, 6, 181-190, 2009.

Sidle, R. C.: Field observations and process understanding in hydrology: essential components in scaling, Hydrol. Process., 20, 1439-1445, 2006.

Simoni, A., Berti, M., Generali, M., Elmi, C., and Ghirotti, M.: Preliminary results from pore pressure monitoring on an unstable clay slope, Eng. Geol., 73, 117-128, 2004.

Singer, J., Schuhbäck, S., Wasmeier, P., Thuro, K., Heunecke, O., Wunderlich, T., and Festl, J.: Monitoring the Aggenalm landslide using economic deformation measurement techniques, Austrian J. Earth Sci., 102, 20-34, 2009.

Skempton, A. W.: Residual strength of clays in landslides, folded strata and the laboratory, Geotechnique, 35, 3-18, 1985.

Suzuki, M. and Kobashi, S.: The critical rainfall for the disasters caused by slope failures, Journal of Japan Society of Erosion Control Engineering (Shin-Sabo), 34, 16-26, 1981.

Takahashi, K.: Research of underground water numerical analysis method that considering water cycle system, $\mathrm{PhD}$ thesis, Kyoto University, Kyoto, Japan, 2004.

Takahashi, K., Ohnish, Y., Xiong, J., and Koyama, T.: Tank model and its application to groundwater table prediction of slope, Chin. J. Rock Mech. Eng., 27, 2501-2508, 2008.

Te Chow, V.: Runoff, in: Handbook of Applied Hydrology, Mc Graw Hill Book Comp, New York City, USA, 14.5-14.8, 1964.

Thuro, K., Wunderlich, T. and Heunecke, O., Singer, J., Schuhbäck, S., Wasmeier, P., Glabsch, J., and Festl, J.: Low cost 3-D early warning system for alpine instable slopes -the Aggenalm Landslide monitoring system, Kostengünstiges 3-D Frühwarnsystem für alpine instabile Hänge - Das Überwachungssystem der Aggenalm-Hangbewegung, Geomechanics and TunnellingGeomechanik and Tunnelbau, 3, 221-237, 2009.

Thuro, K., Singer, J., Festl, J., Wunderlich, T., Wasmeier, P., Reith, C., Heunecke, O., Glabsch, J., and Schuhbäck, S.: New landslide monitoring techniques-developments and experiences of the alpEWAS project, Journal of Applied Geodesy, 4, 69-90, 2010.

Thuro, K., Singer, J., and Festl, J.: A geosensor network based monitoring and early warning system for landslides, in: The Second World Landslide Forum, Abstract Book, edited by: Catani, F., Margottini, A., Trigila, A., and Iadanza, C., Italian National In- 
stitute for Environmental Protection and Research, Rom, S. 267, 79-86, 2011a.

Thuro, K., Singer, J., and Festl, J.: Low cost 3-D early warning system for alpine instable slopes - the Aggenalm Landslide monitoring system, in: Slope stability 2011, International Symposium on Rock Slope Stability in Open Pit Mining and Civil Engineering, Vancouver, Canada, 18-21 September 2011, 12 pp., 2011b.

Thuro, K., Singer, J., and Festl, J.: A geosensor network based monitoring and early warning system for landslides, in: Landslide Science and Practice, Volume 2: Early Warning, Instrumentation and Monitoring, edited by: Margottini, C., Canuti, P., and Sassa, K., Springer, Heidelberg, New York, 79-86, 2013.

Tsaparas, I., Rahardjo, H., Toll, D. G., and Leong, E. C.: Controlling parameters for rainfall-induced landslides, Comput. Geotech., 29, 1-27, 2002.

Uchimura, T., Tanaka, R., Suzuki, D., and Yamada, S.: Evaluation of hydraulic properties of slope ground based on monitoring data of moisture contents, in: Proceedings of the 4th Japan-Taiwan Joint Workshop on Geotechnical Hazards from Large Earthquakes and Heavy Rainfalls, Sendai, Japan, 25-27 October 2010, 85-90, 2010.

Wagner, J. A.: Mean temperature from 1000 to $500 \mathrm{mb}$ as a predictor of precipitation type, B. Am. Meteorol. Soc., 38, 584-590, 1957.
Wang, G. and Sassa, K.: Pore-pressure generation and movement of rainfall-induced landslides: effects of grain size and fine-particle content, Eng. Geol., 69, 109-125, 2003.

Weill, S., Mouche, E., and Patin, J.: A generalized Richards equation for surface/subsurface flow modelling, J. Hydrol., 366, 9-20, 2009.

Wilkinson, P. L., Brooks, S. M., and Anderson, M. G.: Investigating the effect of moisture extraction by vegetation upon slope stability: further developments of a combinedhydrology and stability model (CHASM), British Hydrological Society International Symposium on Hydrology in a Changing Environment, Theme 4: Hydrology of environmental hazards, Exeter, 165-178, 1998.

Wilkinson, P. L., Anderson, M. G., and Lloyd, D. M.: An integrated hydrological model for rain-induced landslide prediction, Earth Surf. Proc. Land., 27, 1285-1297, 2002.

Xiong, J., Ohnish, Y., Takahashi, K., and Koyama, T.: Parameter determination of multi-tank model with dynamically dimensioned search, in: Proc. Symp. Rock mech. Jpn., Sendai, Japan, January 2009, 38, 19-24, 2009.

Yin, Y., Wang, H., Gao, Y., and Li, X.: Real-time monitoring and early warning of landslides at relocated Wushan Town, the Three Gorges Reservoir, China, Landslides, 7, 339-349, 2010. 